\title{
Increasing Literacy Using Drama Activities as Alternative Methods for Malay Language Teaching and Facilitation among Dyslexia Students
}

Lena Farida Hussain Chin, Mohd Kipli Abdul Rahman, Nor Shuradi Nor Hashim

To Link this Article: http://dx.doi.org/10.6007/IJARBSS/v11-i12/10318～DOI:10.6007/IJARBSS/v11-i12/10318

Received: 14 October 2021, Revised: 16 November 2021, Accepted: 30 November 2021

Published Online: 18 December 2021

In-Text Citation: (Chin et al., 2021)

To Cite this Article: Chin, L. F. H., Rahman, M. K. A., \& Hashim, N. S. N. (2021). Increasing Literacy Using Drama Activities as Alternative Methods for Malay Language Teaching and Facilitation among Dyslexia Students. International Journal of Academic Research in Business and Social Sciences, 11(12), 1122-1133.

Copyright: (c) 2021 The Author(s)

Published by Human Resource Management Academic Research Society (www.hrmars.com)

This article is published under the Creative Commons Attribution (CC BY 4.0) license. Anyone may reproduce, distribute, translate and create derivative works of this article (for both commercial and non0-commercial purposes), subject to full attribution to the original publication and authors. The full terms of this license may be seen

at: http://creativecommons.org/licences/by/4.0/legalcode

Vol. 11, No. 12, 2021, Pg. $1122-1133$

http://hrmars.com/index.php/pages/detail/IJARBSS

JOURNAL HOMEPAGE

Full Terms \& Conditions of access and use can be found at http://hrmars.com/index.php/pages/detail/publication-ethics 


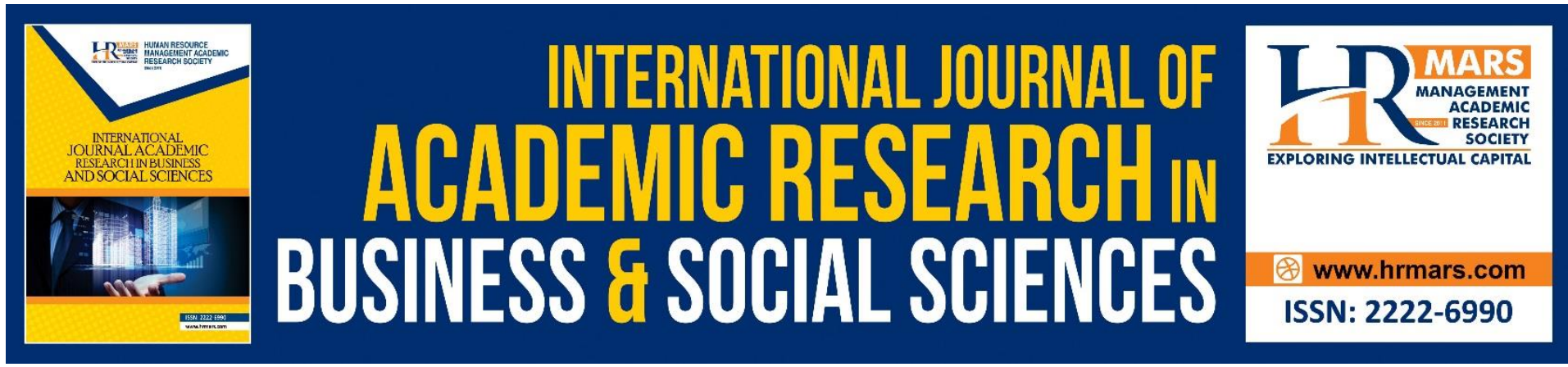

\title{
Increasing Literacy Using Drama Activities as Alternative Methods for Malay Language Teaching and Facilitation among Dyslexia Students
}

\section{Lena Farida Hussain Chin, Mohd Kipli Abdul Rahman, Nor Shuradi Nor Hashim}

Department of Performing Arts, Faculty of Music and Performing Arts, Sultan Idris Education University, Malaysia.

\begin{abstract}
This study was conducted to highlight the method in drama as one of the alternative approaches in teaching and facilitation for primary students with special needs focusing on level 2 in dyslexia. This study looked into how the Malay Language's teaching and learning facilitation can improve their literacy abilities. This research applied two cycles of Kemmis action research. A drama activity module using the Environment and Green Technology theme has been modified based on the Malaysian National Standard Curriculum for Special Education in Primary Schools (KSSRPK) for learning disabilities by referring to the Standard Curriculum and Assessment Document (DSKP) in Malay Language subject. Data collection and structured interviews were organized by observing eight participants who were the respondents. Analysis of the findings of this study has shown that the involvement of drama activities has shown increased alertness and interest in learning the Malay Language. These activities have stimulated the joy of learning in the students. This study proved that the drama method could contribute to communication skills to improve students' literacy abilities, especially in reading and reasoning. The method introduced has fulfilled the policy highlighted by the Ministry of Education Malaysia in implementing Standard Curriculum for Primary School teaching and learning strategies through the Learning through Play (BMB) approach specifically for Students with Special Needs (MBK).
\end{abstract}

Keywords: Drama Activities, Teaching and Facilitation, Dyslexia Students, Students with Special Needs, Learning Through Drama, Drama in Education

\section{Background of the Study}

According to Manon, McAvoy, and Hunt (2015), the drama and education approach to teaching and facilitation is an excellent new method, and this approach is in line with the views and aspirations of user-friendly 21st-century learning. Drama has various components that can be modified according to teaching and facilitation activities. Those who use drama as a medium of teaching and learning have a greater understanding of the role of teachers. Teachers and students practice, make decisions, create new methods, and understand new 
possibilities through drama in an educational context. Actors and drama teachers alike think about how they act and perform to improve their understanding of human intention and interaction in all its complexity. In Malaysia context, the teaching and facilitation in each school are more complicated where more challenges will be faced by the school management, whether teachers. Thus, this is due to the rapid development of technology and further increased education challenges in the 21st century. In the 21st century teaching and facilitation, teachers need to find new approaches, methods, strategies, and teaching techniques. The challenge of 21st-century education is that education geared towards Higher Order Thinking Skills (HLTS) has been practiced in classrooms abroad such as the United States and England since the 1970s. The Malaysian Education Blueprint 2013-2025 in Shift 2 affirms that the government will ensure every child is proficient in Malay and English Language encouraged to learn additional languages. This method is promoted because Malaysian society has cultural diversity. Such an element is intended to create a conducive natural environment to produce students who master more than one language. The current education system is capable of contributing an impressive success in learning Malay Language. One of the policies supported by the National Education Policy is to ensure students have critical thinking skills, creativity, and innovation, have a high sense of national identity as mastering at least two major languages. Therefore, this study was conducted to improve literacy and contribute to developing the Education Policy and Education Development Plan. It is expected to build students' ability to clearly and articulate dialogue through drama activities in Malay Language to strengthen comprehension teaching and facilitation for MBK. In addition, it has the potential to strengthen students' ability to combine verbal and non-verbal language skills as a communication system through role-playing methods. Thus, it also builds MBK students' ability in reading and reasoning on the information transfer process through play role-playing simulations.

\section{Statement of Problem}

One of the policies highlighted in the national education policy is improving students' mastery of literacy skills before entering level two of primary school. However, there are studies in 2008 that showed that $13 \%$ of 54000 Year 1 students do not master $2 \mathrm{M}$ (writing and reading). These two essential skills are significant factors that will facilitate learners' understanding of learning. The failure in achieving these two skills will lead to difficulty in understanding learning. In response to this policy, Kemmis action research was applied to investigate the extent to which drama potential could be an alternative method in Malay Language teaching and learning facilitation among level 2 dyslexia students to improve literacy skills. Most level two (2) students from dyslexia classes still have literacy problems, especially in reading involving three syllables and more. It is undeniable that various traditional teaching and learning methods and inquiry learning have also contributed to teaching students with special needs. Among the methods that have been adapted are from drama activities such as simulation methods and role play. However, from the initial observations and readings done, the researcher argues that this method still has a great potential to be reinforced with various drama method activities that can contribute to students' development in overcoming existing literacy problems.

Besides, this study is also expected to enrich the innovation of the existing teaching and facilitation. In this matter, the Ministry of Education Malaysia has stated that Special Education (Learning Disabilities) Primary School Curriculum Standard (KSSR) formulated by 
the National Education Philosophy based on integrated approach principles, individual holistic development, educational opportunities, and equal quality of education for all students as well as lifelong education. Special Education KSSR (Learning Disabilities) in Science, Social and Environmental Education (PSSAS) is holistic and can be modified to suit the needs of students with special needs (MBK) in line with what is intended in the Development Plan Malaysian Education (PPPM) 2013-2025. The main goal of KSSR Special Education (Learning Problem) Malay Language enacted to enable special needs students to acquire speaking skills and communicate to meet personal needs, acquire knowledge, skills, information, values, and ideas, and improve social relationships in daily life. For that purpose, drama activities have good potential at building these skills. Drama is literature written in format dialogue to be staged (Mobley, 1992). It is a literary work that consists of an effective communication system based on the dialogue contained therein. In addition to reading, drama activities have a variety of simulation ways to be applied. Among them are dramatic writing, storytelling, roleplay, improvisation, acting, theater games, action construction, etc.

Moore (2004) explains that using drama in the classroom as a way of teaching helps students learn in the field of academic, social, and mental development. The use of drama as a tool for teaching is not new. Historically, drama has long been recognized as an effective medium of indoctrination in education. Therefore, the justification of this study is to respond to the national education policy to improve mastery of literacy skills. To improve this literacy mastery, this study aims to contribute to inclusive teaching and learning facilitation methods in enriching existing teaching methods. This study's objective focuses on identifying the contribution of drama simulation teaching and facilitation activities to better understanding Malay Language. After the identification process, this study will analyze and justify the potential activities of the drama simulation method as enrichment to teaching and learning facilitation methods. A module designed specifically for this study will be constructed based on the reflections. Applying the method of drama in teaching and learning facilitation for Malay Language will diversify those conventional methods to be more effective with various enjoyable learning activities while developing students' literacy potential in the Malay Language subject. Hopefully, the results of this study can clarify the advantages of drama as an alternative method in improving literacy abilities of students of dyslexia students, especially in reading and reasoning, as well as acting as a contribution in increasing the choice of existing methods.

\section{Objectives}

This research objectives are to identify and analyze the possible contributions of drama simulation activities that can increase the understanding of the Malay Language. Further to this, it is a support effort to justify drama simulation activities (writing, reading, storytelling, and role-playing) as a potential alternative method of teaching Malay Language to improve students' literacy.

\section{Methodology}

This research was conducted to examine the learning impact and understanding of the Special Needs student's (MBK) learning disabilities at Sekolah Kebangsaan Bayan Baru (SKBB) through drama activities as an alternative method of teaching and learning facilitation for Malay Language. The research focuses on the Malay Language among level 2 dyslexia students to improve literacy abilities. This study is a qualitative study that uses Kemmis action research 
approach involving two cycles. A drama activity module has been modified based on the National Special Education Primary School Standard Curriculum (KSSRPK) (Learning Problems), which refers to the Curriculum and Assessment Standard Document (DSKP) of Malay Language for Special Learning (Dyslexia 2). Environmental and Green Technology topic selected for the implementation of this study.

In addition to activities, data collection was done by observing participants who were also actively involved in the activities. Structured interviews were conducted on eight respondents from the Dyslexia Two (2) class. Modified drama simulation activities include Content Standards 1 to 4 in DSKP and textbooks. Students who are respondents for this study were randomly selected. Subsequently, the researcher has made observations on the effectiveness of the methods introduced by conducting activities and impact reflections based on it. In addition to observation methods, research instruments involve surveys and structured interviews; secondary sources from the library on drama and education will also comprehensively support the implementation of this study.

Figure 1: Research Framework

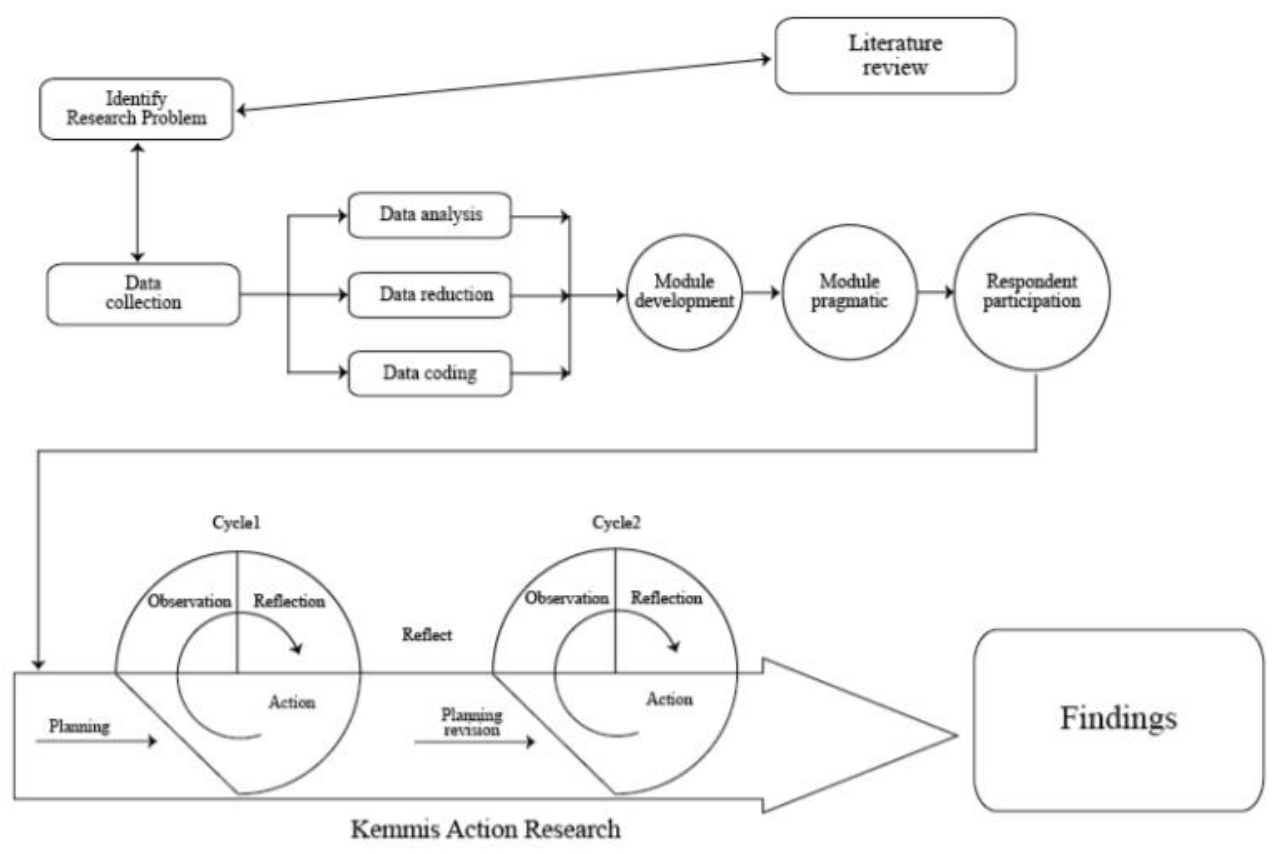

\section{Literature Review}

Sulaiman (1980) found that the implementation of drama techniques in Malay Language pedagogical KBSR ${ }^{1}$ able to achieve the program's objectives through drama activities such as acting, role play, and improvisation. For example, through role-playing techniques, students can speak and express ideas using appropriate language in various forms of communication. This shows that students can be more creative in fun learning activities.

1 In 1983, the Malaysian education system introduced the New Primary School Curriculum (KBSR), which focused on mastering basic skills. Efforts to address the problem are carried out through the Special Rehabilitation Program established in each primary school 
Sikana(1985) stated that although the nature of the drama consists of an exclusive branch of art, it can be used in teaching and learning facilitation. In 1989, Hamzah, R. K. explained that drama techniques in the classroom could build high intellectual thinking, language development, and good social interaction. Further that, the application of drama techniques in teaching and learning the Malay Language, especially in primary schools, could play a catalytic role in the effort and increase understanding of the subject matter and fertilize interest in learning among students.

In the West, Edmiston (2000) explains that the potential of drama as an educational ethic is acknowledged by several scholars such as Colby, Winston, and Edmiston. Further explained in a book entitled Drama, Narrative and Moral Education by Winston (1998) has highlighted the discussion on the capabilities and advantages of drama as an educational ethic.

In addition, Jacob (2005) believed children involved with drama activities such as stories and scripts successfully show improvement in story comprehension and can read new material even when given the first time. The effect significantly for children with reading difficulties and children who cannot spend heavily on remedial classes.

Even though Jamian (2011) research shows there are problems in students to master reading and writing skills in Malay Language, including a basic knowledge of reading and writing, the environment, and teaching methods. Findings of the study in reading skills showed that the failure of students to understand the content of information in the text reads (mean $=3.40 ; \mathrm{sp}=.71$ ) and did not understand the meaning of the sentences read (mean = $3.24 ; \mathrm{sp}=.60$ ). While the findings of the study on writing skills problems showed that students were unable to distinguish uppercase or lowercase letters through recognition (mean $=3.62$; $\mathrm{sp}=.62$ ), in addition, recognizing punctuation (mean $=3.42 ; \mathrm{sp}=.80$ ) . In conclusion, to overcome this problem, he suggested that remedial education is a vehicle that can help increase students who have problems in reading and writing skills. Early rehabilitation programs will have a more effective impact in efforts to strengthen education in our country.

Since 1980, various studies and academic recommendations on drama simulation activities as a teaching method have been written and workshopped in Malaysia. However, in Malay Language teaching, the conventional method remains the top choice for teaching and learning activities. Moreover, until 2011, the study still shows students' problems with mastering reading and writing in Malay Language. This action research aimed at filling the existing research gaps. Action research and academic recommendations regarding simulation drama activities as an alternative method of teaching Malay Language will be carried out by introducing several modules elected referring to the Malay Language KSSR curriculum to perceive the effect and impact of the recommendations of this alternative method. Hopefully, it succeeds in diversifying teaching and learning methods to help develop various levels of intelligence to obtain more optimal learning abilities.

\section{Findings}

Tables 1 and 2 show the demographics of the gender distribution and age of the respondents in this study. The age of the respondents for this study ranged from 10 years to 13 years. Even though the study is based on Malay Language subjects for Level 2 Dyslexia, the age 
distribution of students is random based on the needs of individuals with learning disabilities. Dyslexia classes do not apply according to the age of standard school students.

\begin{tabular}{r|l|l|} 
Sex & Frequency & Percentage (\%) \\
\hline Boys & 4 & 50 \\
Girls & 4 & 50 \\
Total & $\mathrm{N}=8$ & 100 \\
\cline { 2 - 3 } & &
\end{tabular}

Table 1: Gender of respondents $(\mathrm{N}=8)$

\begin{tabular}{|c|c|c|}
\hline Age & Frequency & Percentage (\%) \\
\hline 10 & 3 & 37 \\
\hline 11 & 2 & 25 \\
\hline 12 & 1 & 13 \\
\hline 13 & 2 & 25 \\
\hline Total & $\mathrm{N}=8$ & 100 \\
\hline
\end{tabular}

Table 2: Age of respondents

Based on Table 2, the most common age distribution in this study is ten years old who is represented $37 \%$. Respondents aged 11 years and 13 each year are 25\%, while 12 years respondents are $13 \%$. All respondents are Malay, and Malay Language is their native language. This study is based on the Standard Primary School Curriculum of National Special Education (KSSRPK) (Learning Disabilities), which refers to the Document Standard Curriculum and Assessment (DSKP) Special Learning Dyslexia 2 Malay Language. The four main points in the DSKP Content Standard (SK) were used as a super basis for this study. Tables 3, 4, 5, and 6 below refer to the relevant SK. However, this study's teaching and learning activities have been replaced by drama method modifications.

Table 3 below is the score showing the achievement category indicator

\begin{tabular}{|l|l|}
\hline Score & $\begin{array}{l}\text { Achievement Category } \\
\text { Indicator }\end{array}$ \\
\hline 4 & Excellent \\
\hline 3 & Good \\
\hline 2 & Fair \\
\hline 1 & Poor \\
\hline
\end{tabular}

Table 3: Scores showing the achievement category indicator

Table 4 below shows data analysis related to evaluation instruments through observations based on observer responses to verbal comprehension. There are five things analyzed from an oral comprehension aspect. 


\begin{tabular}{lc}
\hline \multicolumn{1}{c}{ Item } & Average $(\overline{\mathbf{x}})$ \\
\hline 1. Listen to instructions & 3.875 \\
\hline 2. Listen and understand instructions & 3.75 \\
\hline 3. Hear and understand stories & 3.875 \\
\hline 4. Respond to stories read & 3.625 \\
\hline 5. Understand the story based on the picture & 4.0 \\
\hline
\end{tabular}

Table 4: SK 1.0 Listening and Speaking Skills (Modification of story dramatization)

Referring to item one, which is listening to instructions, the results of the data analysis show a total of seven respondents got the highest score reading with a total of four points (excellent), while only one respondent got a score reading with a total of three points (good). Therefore, the average reading for listening direction was 3.875. Next, item two, under the aspect of oral comprehension, is listening and understanding the instructions. Assessment results based on the teacher's response to the subject show that six respondents got the highest score reading with four points (excellent), while the other two respondents got the second-highest score reading with a total of three points (good). The average reading for listening and understanding the instructions mean was 3.75. As for listening and understanding stories, the results of data analysis show that seven respondents achieved the highest score reading of four points with a very good category, while only one respondent got a score reading totaling three points with a good category average reading mean 3,875 .

Data analysis based on four items that are responding to a story heard, there are a total of five respondents who embraced the highest score reading totaled four points with excellent category, while the respondent scored the second-highest score reading amounting to three points under the good category is a total of three people. Therefore, the average reading for item four under the aspect of oral comprehension mean was 3,625. To evaluate point five, which is understanding the story based on pictures, data analysis shows that the eight respondents got the highest score reading under the excellent category with four points and making an average reading of item five with the mean score of 4 .

Table 5 shows the data analysis related to evaluation instruments through observation based on observer responses to aspects of reading skills. Five items were analyzed under the aspects of reading skills.

\begin{tabular}{lc}
\multicolumn{1}{c}{ Item } & Average $(\overline{\mathbf{x}})$ \\
\hline 1. Sound the syllables KVKK+KV & 3.75 \\
\hline 2. Spell and stem the word KVKK+KV & 3.75 \\
\hline 3. Spell and stem conjoined vowel words & 3.5 \\
\hline 4. Read aloud the words you have learned & 3.75 \\
\hline $\begin{array}{l}\text { 5. Read aloud phrases that contain learned } \\
\text { words }\end{array}$ & 3.625 \\
\hline
\end{tabular}

Table 5: SK 2.0 Reading Skills (Modification by reading drama dialogue)

Referring to item one, which is uttering the syllable KVKK + VK (Consonant Vowel Consonant Consonant + Vowel Consonant), the result of the analysis data reveals that six respondents got the highest score reading with a total of four points (excellent), while two respondents got the second-highest score reading with a total of three points (good). Therefore, the mean score for average reading for the syllable sound of KVKK + VK was 3.75. 
Next, the second item under reading skills is spelling and reading the word KVKK + VK. The assessment results showed that seven people respondents got the highest score reading with four points (excellent), while only one respondent got an average score reading with two points. The average reading for spelling and spelling words KVKK + VK is mean $=3.75$.

As for the matter of spelling and reading two-vowel together, the result of data analysis showed that five respondents achieved the highest score reading with a total of four points in an excellent category, two respondents achieved good score reading with a total of 3 points while only one respondent got an average reading score with a score of two. This amount makes the reading average of a total mean $=3.5$. Data analysis based on item four, namely reading aloud words learned, six respondents, got the highest score reading, which totaled four points with an excellent category. In comparison, two respondents who got the second-highest score reading amounting to three points under the good category are three people, which shows the average reading of the four items under the reading skills aspects is mean $=3.75$. For the evaluation of item five, which is to read aloud the phrase containing the word that has been studied, data analysis shows as many as five respondents got the highest score reading with a total of four points (excellent), while three people respondents who got the second-highest score reading with a total of three points (good). The results of the data analysis show that the average of five items is mean $=3.625$.

Table 6 shows the data analysis related to evaluation instruments through observation based on observer responses of writing skills aspects. Five things analyzed under aspects of writing skills.

\begin{tabular}{lc}
\hline \multicolumn{1}{c}{ Item } & Average $(\overline{\mathbf{x}})$ \\
\hline 1. Write syllables & 3.625 \\
\hline 2. Write words and phrases & 3.625 \\
\hline 3. Write a single sentence & 3.5 \\
\hline 4. Write using punctuation & 3.25 \\
\hline 5. Produce writing & 3.25 \\
\hline
\end{tabular}

Table 6: SK 3.0 Writing Skills (Modification of drama writing)

Referring to item one, which is writing syllables, it has shown that five respondents obtained the highest score reading amounting to four points with the excellent category, while the three respondents who got the second-highest score read a total of three points under the category. The average for item four under the reading skill aspects is mean = 3,625. The same findings refer to the matter of writing words and phrases. However, writing a single sentence showed five to seven respondents achieved the highest score reading of four points with excellent category, while two respondents got a good score reading of 3 points and one reached the moderate category with a score of two. Overall average reading means $=3.25$. While writing using punctuation and producing writing shows that three respondents got the highest total score reading of four points in the excellent category, four respondents got the second-highest score reading totaling three points under the good category, and one got an average reading score of two points. Therefore, the average reading for item four below aspect of reading skills is mean $=3.25$. 
Table 7 below shows the data analysis related to evaluation instruments through observations based on observer responses to aspects of writing skills. There are five things analyzed under aspects of writing skills.

\begin{tabular}{lc}
\hline \multicolumn{1}{c}{ Item } & Average $(\overline{\mathbf{x}})$ \\
\hline 1. Storytelling & 3.375 \\
\hline $\begin{array}{l}\text { 2. Simulate movement and role play by } \\
\text { improvisation }\end{array}$ & 3.625 \\
\hline 3. Act based on a drama scenario & 3.375
\end{tabular}

Table 7: SK 4.0 Aspects of Language Arts (Modification of drama performance)

The results of data analysis of one item that is storytelling show a total of eight people respondents got the highest score reading with a total of four points (very good), while two respondents got the second-highest score reading with the number of points as many as three (good). Therefore, the average reading for item one shows a mean $=3.75$. Item two under aspects of singing and movement (Replaced by simulation and role play improvisation) shows a total of five respondents got the highest score reading amounting to four points with excellent category. In contrast, respondents who got the second-highest score reading that amounted to three points below the good category is three people. Therefore, the average reading for item four below aspect of reading skills is mean $=3.625$. The result of data analysis of the third item referring to acting based on a drama scenario shows that seven respondents achieved the highest score reading amounting to four points with excellent category. In contrast, only one respondent got an average score reading with two, further making the average reading amount to mean $=3.75$.

Based on the analysis of the findings of the activities conducted among respondents, using the drama method for teaching and facilitation Malay Language (Learning Disabilities) can foster understanding of literacy. Seven questions were designed to identify the extent of respondents' knowledge or understanding of the method of dramatization after the study was conducted. Data analysis questionnaire before the study showed that only 2 respondents indicated an interest in response to drama techniques for handling events in Malay Language Teaching and learning facilitation. However, after the activities were carried out, the increased interest in drama methods has increased by $100 \%$. Based on observations throughout the handling of drama activities, the researcher found that all respondents enjoyed teaching and learning facilitation time by actively engaging in the activities. The analysis of the questionnaire data showed that only two respondents felt happy to participate in the activity before it was conducted. However, after the events occur, the data obtained showed that all respondents expressed having fun with activities that use drama methods. All respondents were found to be actively involved in performing all drama activities carried out. The researcher also found that implementing simulation exercises in learning Malay Language help promote understanding and literacy in students with learning disabilities. These methods of teaching and facilitation can improve soft skills in communication, teamwork, and resilience and develop a sense of natural curiosity to explore strategies and new ideas. The respondents' positive response and their seriousness in performing activities/tasks prove that drama activities as an alternative method of teaching and learning facilitation are suitable according to the level of ability of MBK. In addition, this method dramatically stimulates the Learning through Play (BMB) approach. Through the analysis of the study, this method is seen to be able to attract interest and create fun while learning and even able to create a fun 
learning environment besides being able to foster literacy understanding among MBK students.

\section{The Benefit to the Nation}

The findings of this study have demonstrated the contribution of Malay drama (drama activities are modified by Standard Composition 1 to 4 contained in DSKP) (Learning Disabilities) in improving understanding of learning Malay Language through conducted activities. This matter is due to the stimulation of fun learning among students. This method has excellent potential to be highlighted as a teaching and learning facilitation method to enrich the existing method further. In addition, the findings of the study also revealed that teaching and learning facilitation using this drama method could improve communication skills to improve students' literacy abilities, particularly in reading and reasoning. The method introduced is seen to fulfill the policy presented by the Ministry of Education Malaysia in implementing KSSR teaching and learning strategies through the Learning through Play (BMB) approach for students, especially MBK to attract interest and create fun learning. Additionally, the study results also indicate that teaching and learning using drama methods have stimulated students' thinking skills. This method cultivates communication skills, teamwork, and resilience develops a natural curiosity to explore new strategies and ideas based on life skills and noble values. Thus, such a study should be given attention and opportunity because it has excellent potential to increase 21st-century learning options and further achieve various methods in the new millennium teaching and learning facilitation, especially for MBK.

Contextually, the contribution of this study shows drama methods capable of achieving the main goal set by Malaysian Primary School Standard Curriculum Special Education (Learning Disabilities) for Malay Language subjects. This specially formulated curriculum enables MBK to master language and communication skills to meet personal needs, acquire knowledge, skills, information, values, and ideas, and improve social relationships in daily life in parallel with drama activities carried out. The drama method applied showed a surge of MBK interest in learning activities. Drama activities have good potential in building these skills as supported by the Malaysian National Education Policy to ensure that students have critical thinking skills, creative, innovative, have high national identity values, and master at least two main languages, mainly Malay and English. The main goal KSSR Special Education (Learning Disabilities) Malay Language enacted to enable MBK to master language skills and ability to communicate to meet the needs of self, acquire knowledge, skills, information, values, and ideas to improve social relations in everyday life. To that end, undeniable drama has excellent potential in building these skills by empowering various teaching and facilitation learning styles.

\section{Acknowledgments}

This study is funded by Geran Penyelidikan Universiti (UPSI: 2018-0222-107-01) from Universiti Pendidikan Sultan Idris.

\section{References}

Napiah, A. R. (1987). Drama moden Malaysia: Perkembangan dan perubahan. Kuala Lumpur: Dewan Bahasa Pustaka.

Jamian, A. R., \& Sujud, A. (2001). Media pengajaran: Pengajaran bahasa dan sastera. Kuala Lumpur: Kumpulan Budiman Sdn. Bhd. 
Jamian, A. R. (2011). Permasalahan kemahiran membaca dan menulis Bahasa Melayu muridmurid sekolah rendah di luar bandar. Jurnal pendidikan bahasa Melayu. Universiti Kebangsaan Malaysia. Vol. 1, Bil. 1 (Mei 2011): 1-12.

Jamian, A. R., \& Zarin, Z. A. (2008). Penguasaan kemahiran membaca dan menulis dalam kalangan murid sekolah rendah. Prosiding KONPEN 2008. 1-4 Jun.

Sulaiman, E. (2004). Pengenalan pedagogi. Johor: Universiti Teknologi Malaysia.

Gardner, H. (2011). Frames of mind: The theory of multiple intelligences. New York: Basic Books.

Jacobs \& Michael. (2005). Thesis: Drama discovery. Pittsburgh: Duquesne University.

Kemmis, H., McTaggart, R., \& Nixon, R. (2013). The action research planner: Doing critical participatory action research. Australia: Springer.

Sulaiman, F. (1995). Drama dalam pendidikan bahasa. K. Lumpur: Bahagian Pendidikan Guru.

Arshad, M. (2008). Literasi Bahasa Melayu. Kuala Lumpur: Utusan Publications \& Distributors Sdn Bhd.

Water, M. V. D., McAvoy, M. \& Hunt, K. (2015). Drama and education: performance methodologies for teaching and learning. New York \& London: Routledge.

Moore, M. M. (2004). Using drama as an effective method to teach elementary students. Michigan: Eastern Michigan University.

Lebar, O. (2011). Kajian tindakan dalam pendidikan. Tanjong Malim: Universiti Pendidikan Sultan Idris.

Bujang, R. (1989). Falsafah dan matlamat drama dalam pendidikan. Kerta Kerja Seminar Kebangsaan Drama Dalam Pendidikan. Serdang: Universiti Pertanian Malaysia (14-15 Okt)

Hamzah, R. K. (1989). Pengendalian aktiviti drama dalam pendidikan di luar bilik darjah. Kerta Kerja Seminar Kebangsaan Drama Dalam Pendidikan. Sedang: Universiti Pertanian Malaysia (14-15 Okt)

Pelan Pembangunan Pendidikan 2013-2025. (2013). Retrieved 2016, from http://www.moe.gov.my/my/pelan-pembangunan-pendidikan-malaysia-2013-2025

Dasar Pendidikan Kebangsaan. (2012). Retrieved 2016, from http://www.moe.gov.my/my/dasar-pendidikan-kebangsaan 